\title{
Sarcoid Granulomatous Interstitial Nephritis Accompanied by Type 2 Diabetes Mellitus.
}

\author{
Takashi Nagai, ${ }^{1}$ Makoto Imamura, ${ }^{1}$ Takao Ishizuka, ${ }^{1}$ \\ and Masatomo Mori ${ }^{2}$
}

\begin{abstract}
A 54-year-old type 2 diabetic woman had suffered from clouded vision indicating uveitis. Funduscopic examination showed retinal vein dilatation without diabetic retinopathy. Although urinalysis showed - to \pm protein, the serum creatinine elevated. Urinary albumin excretion rate; $29 \mathrm{mg} / \mathrm{g} \cdot$ creatinine and urine $\beta 2$-microglobulin; $9600 \mu \mathrm{g} / 1$ reflected increased tubular protein excretion. Renal biopsy showed non-caseous granuloma with lymphocytic infiltration in the renal interstitium. It did not show diabetic nephropathy. The chest computed tomograms showed slightly peripheral granular shadow in bilateral lower lung fields. Pulmonary uptake of gallium-67 was positive. We diagnosed sarcoidosis accompanied by diabetes mellitus. The renal dysfunction may be caused by sarcoid granulomatous interstitial nephritis. We began giving her 40mg of methylprednisolone daily for renal involvement due to sarcoidosis. After blood glucose elevation, we then changed from glibenclamide to insulin therapy. The clouded vision subsequently recovered. Serum creatinine and urine $\beta 2-$ microglobulin returned to normal range. (Kitakanto Med J $2004 ; 54: 317 \sim 320$ )
\end{abstract}

Key Words : sarcoidosis, diabetes mellitus, creatinine, $\beta 2$-microglobulin

Introduction

Sarcoidosis is a systemic inflammatory disease characterized by accumulation of lymphocytes and noncaseating epithelioid granuloma in affected organs. Understanding of the possible mechanism of granuloma formation has been increased through immunological studies. ${ }^{1}$ Although autopsy series have demonstrated that renal involvement is present in 7 to $27 \%$ of patients with sarcoidosis, ${ }^{2}$ less than $1 \%$ of the patients with known sarcoidosis develop renal insufficiency ${ }^{3}$ Renal involvement signs vary from slightly increased creatinine to renal failure. Proteinuria or even nephrotic syndrome may occur. ${ }^{2}$ Autoimmune endocrine disease and sarcoidosis may be related, ${ }^{4}$ however, association of type 1 diabetes mellitus with sarcoidosis is rare. ${ }^{5,6}$ We report on a case of sarcoid granulomatous interstitial nephritis accompanied by type 2 diabetes mellitus. It is important to differentiate sarcoid renal lesion from diabetic nephropathy.

\section{Case report}

A 54-year-old type 2 diabetic woman had suffered from clouded vision since early May. From the middle of May papule appeared in her right leg. The serum creatinine elevated from June with urine protein - to \pm . Diabetes mellitus was diagnosed at age 49. After that she came to our hospital for treatment. The HbAlc ranged from 6.8 to $7.2 \%$ for 5 years by diabetic diet and glibenclamide of $1.25 \mathrm{mg}$ daily. She had not taken other drugs. She did not drink alcohol or smoke. Her family had no previous history of diabetes mellitus, nor was there a previous history of any other major illness.

Physical examination showed the following: height $152 \mathrm{~cm}$, weight $45 \mathrm{~kg}$ (body mass index $19.5 \mathrm{~kg}$ / $\mathrm{m}^{2}$ ), blood pressure $128 / 74$, pulse rate $66 / \mathrm{min}$ and temperature $36.8^{\circ} \mathrm{C}$. Her face, nose or ears showed nothing particular. Her conjunctiva was not anemic. On funduscopic examination there were retinal vein dilatation and periphlebitis without diabetic

1 Department of Internal Medicine, Public Tomioka General Hospital, Tomioka, Gunma, 370-2393, Japan

2 Department of Medicine and Molecular Science, Gunma University School of Medicine, Maebashi, Gunma, 370-8511

Received: September 16, 2004

Address: TAKASHI NAGAI Department of Internal Medicine, Public Tomioka General Hospital, 2073-1 Tomioka, Tomioka, Gunma, 370-2393, Japan 
Table 1 Laboratory data on admission

\begin{tabular}{|c|c|c|c|c|c|}
\hline Urinalysis & & Chemistry & & & \\
\hline protein $(-)$ & & AST & $14 \mathrm{IU} / 1$ & ferritin & $110 \mathrm{ng} / \mathrm{ml}$ \\
\hline glucose $(-)$ & & ALT & $17 \mathrm{IU} / 1$ & erythropoietin & $2.7 \mathrm{mIU} / \mathrm{ml}$ \\
\hline blood $(-)$ & & $\mathrm{LDH}$ & $146 \mathrm{IU} / 1$ & fasting plasma glucose & $84 \mathrm{mg} / \mathrm{dl}$ \\
\hline acetone $(-)$ & & ALP & $103 I U / 1$ & HbAlc & $7.0 \%$ \\
\hline $\mathrm{pH} 5$ & & $\gamma^{-\mathrm{GTP}}$ & $9 \mathrm{IU} / 1$ & urine-CPR & $52 \mu \mathrm{g} /$ day \\
\hline $\mathrm{RBC}$ & $1-2 / \mathrm{hpf}$ & total protein & $7.5 \mathrm{~g} / \mathrm{dl}$ & GAD-Ab & $0.3 \mathrm{U} / \mathrm{ml}$ \\
\hline WBC & $1-2 / \mathrm{hpf}$ & albumin & $4.1 \mathrm{~g} / \mathrm{dl}$ & thyroglobulin $\mathrm{Ab}$ & $0.1 \mathrm{U} / \mathrm{ml}$ \\
\hline cast $(-)$ & & ZTT & $9.5 \mathrm{U}$ & thyroid peroxidase $\mathrm{Ab}$ & $0.1 \mathrm{U} / \mathrm{ml}$ \\
\hline Hematolog & & TTT & $3.9 \mathrm{U}$ & creatinineclearance & $52.7 \mathrm{ml} / \mathrm{min}$ \\
\hline $\mathrm{RBC}$ & $414 \times 10^{4} / \mu 1$ & BUN & $28.1 \mathrm{mg} / \mathrm{dl}$ & urinary albumin excretion & $29 \mathrm{mg} / \mathrm{g}$ \\
\hline $\mathrm{Hb}$ & $11.2 \mathrm{~g} / \mathrm{dl}$ & creatinine & $1.8 \mathrm{mg} / \mathrm{dl}$ & creatinine urine $\mathrm{N}$-acetylglucosaminidase & $24.4 \mathrm{U} / 1$ \\
\hline $\mathrm{Ht}$ & $38.3 \%$ & uric acid & $7.3 \mathrm{mg} / \mathrm{dl}$ & urine $\beta 2$-microglobulin & $9600 \mu \mathrm{g} / 1$ \\
\hline platelet & $29.7 \times 10^{4} / \mu 1$ & $\mathrm{Na}$ & $139 \mathrm{mEq} / 1$ & angiotensin converting enzyme & $18.1 \mathrm{IU} / 1 \cdot 37^{\circ} \mathrm{C}$ \\
\hline WBC & $6900 / \mu 1$ & $\mathrm{~K}$ & $4.4 \mathrm{mEq} / 1$ & Serology & \\
\hline Basophil & $1 \%$ & $\mathrm{Cl}$ & $100 \mathrm{mEq} / 1$ & CRP & $0.1 \mathrm{mg} / \mathrm{dl}$ \\
\hline Eosinophil & $7 \%$ & $\mathrm{Ca}$ & $10.5 \mathrm{mg} / \mathrm{dl}$ & HBsAg $(-)$ & \\
\hline Seg & $50 \%$ & $\mathrm{P}$ & $4.4 \mathrm{mg} / \mathrm{dl}$ & $\mathrm{HCV}(-)$ & \\
\hline Lymph & $34 \%$ & amylase & 149IU/1 & & \\
\hline Monocyte & $7 \%$ & total cholesterol & $218 \mathrm{mg} / \mathrm{dl}$ & & \\
\hline ESR & $23 \mathrm{~mm} / \mathrm{hr}$ & $\begin{array}{l}\text { HDL-cholesterol } \\
\text { triglyceride }\end{array}$ & $\begin{array}{r}37 \mathrm{mg} / \mathrm{dl} \\
146 \mathrm{mg} / \mathrm{dl}\end{array}$ & & \\
\hline
\end{tabular}

retinopathy, diagnosing posterior uveitis. There were no abnormalities on the neck, chest and abdomen. There was no lymphadenopathy. Papule was noted in her right leg. Arterial pedia dorsalis pulse was palpable on both sides. The tendon reflexes were symmetrically normal in the tetra limbs. There were no abnormalities in sensation.

Laboratory data on admission are shown in Table 1. Urinalysis and liver function were within a normal range. Hemoglobin; $11.2 \mathrm{~g} / \mathrm{dl}$, eosinophil ; 7\%, blood urea nitrogen $(\mathrm{BUN}) ; 28.1 \mathrm{mg} / \mathrm{dl}$, creatinine ; 1 . $8 \mathrm{mg} / \mathrm{dl}$, Ca $; 10.5 \mathrm{mg} / \mathrm{dl}$, ferritin ; $110 \mathrm{ng} / \mathrm{ml}$, erythropoietin; $2.7 \mathrm{mIU} / \mathrm{ml}$ (indicating renal anemia), fasting blood glucose (FBG); 97mg/dl, HbA1c; 7.0\%, urine $\mathrm{C}$-peptide reactivity; $52 \mu \mathrm{g} / \mathrm{day}$, glutamic acid decarboxylase antibody (GAD-Ab);0.3U $/ \mathrm{ml}$, thyroglobulin antibody; $0.1 \mathrm{U} / \mathrm{ml}$ and thyroid peroxidase antibody; $0.1 \mathrm{U} / \mathrm{ml}$ (indicating type 2 diabetes mellitus), creatinine clearance ; $52.7 \mathrm{ml} / \mathrm{min}$, urinary albumin excretion rate; $29 \mathrm{mg} / \mathrm{g} \cdot$ creatinine, urine $\mathrm{N}$ acetylglucosaminidase ; $24.4 \mathrm{U} / 1$ and urine $\beta 2$ microglobulin; $9600 \mu \mathrm{g} / 1$. Angiotensin converting enzyme (ACE) was $18.1 \mathrm{IU} / 1 \cdot 37^{\circ} \mathrm{C}$.

There was no abnormality in the chest $\mathrm{x}$ ray, abdominal echogram or electrocardiogram. Pulmonary uptake of gallium-67 was positive, however, bilateral renal uptake was not shown (Fig. 1a). The chest computed tomograms showed slightly peripheral granular shadow in bilateral lower lung fields (Fig. 1b). Tuberculin reaction was negative $(0 \mathrm{~mm} \times 0 \mathrm{~mm})$. A skin biopsy specimen showed a non-caseous granuloma with lymphocytes and polynuclear giant cells infiltration (Fig. 2a). A renal biopsy specimen

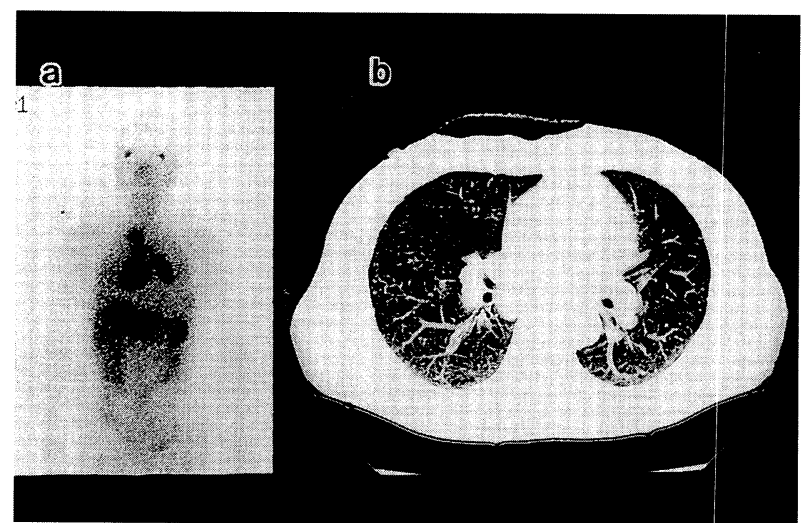

Fig. 1a Pulmonary uptake of gallium-67 is positive, however, bilateral renal uptake is not shown.

1b Chest computed tomography showing slightly periphcral granular shadow in bilateral lower lung fields.

showed non-caseous granuloma with lymphocytes and polynuclear giant cells infiltration in the renal interstitium and did not show diabetic nephropathy (Fig. 2b). We diagnosed as sarcoidosis based on uveitis, pulmonary picture finding and pathological finding of skin and kidney. We started to give her 40mg of methylprednisolone daily. Then we had changed from glibenclamide to insulin therapy after blood glucose elevation. After that clouded vision recovered. Serum creatinine and urine $\beta 2$-microglobulin returned to normal range (Fig. 3).

\section{Discussion}

Acute uveitis and tubulointestinal nephritis suggested a differential diagnosis from idiopathic tubulointestinal nephritis with uveitis. In contrast to sarcoidosis, the lymphocytic interstitial infiltrate may 

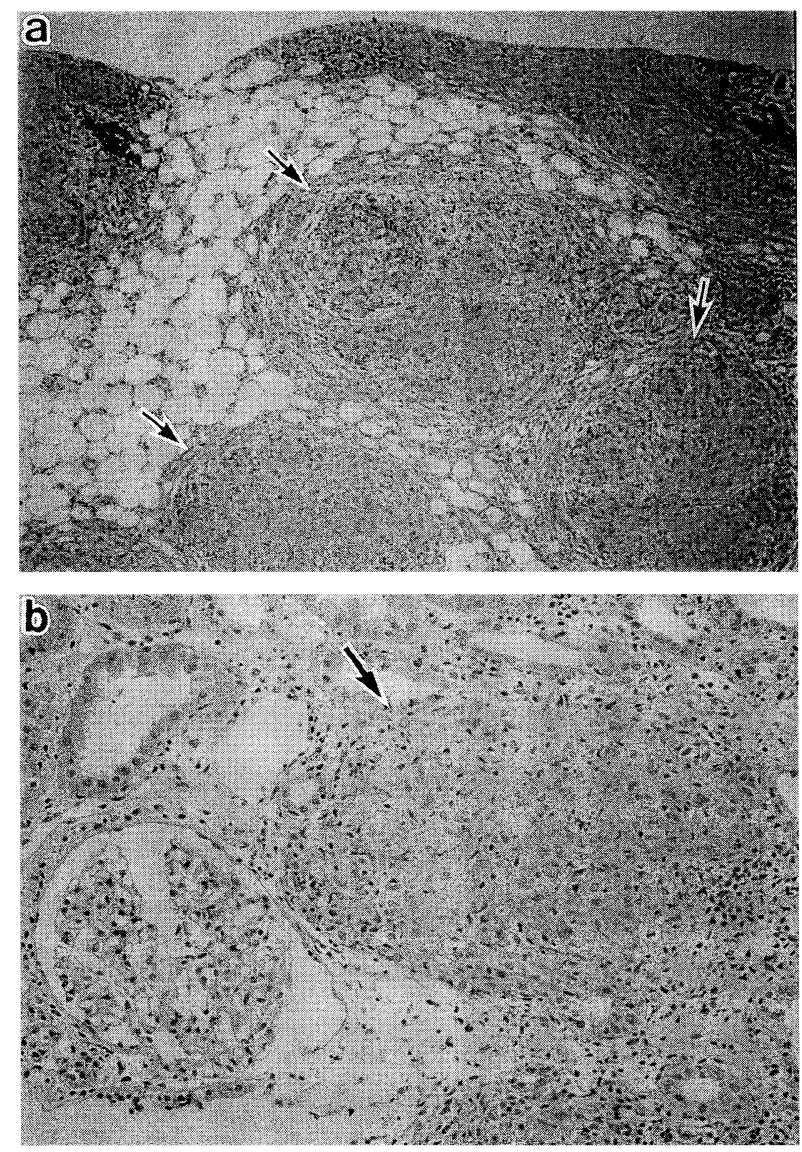

Fig. 2a There are granulomatous tissues in the skin lesion (HE stain $\times 100$, the arrows indicate).

2b There are granulomatous tissues in the renal interstitium (PAS stain $\times 100$, the arrow indicates). be accompanied by abundant eosinophils. ${ }^{7} \mathrm{We}$ diagnosed the patient sarcoidosis accompanied by diabetes mellitus resulting from posterior uveitis, probable pulmonary lesion, and skin and renal biopsy which showed non-caseous granuloma with lymphocyte and polynuclear giant cell infiltration in the absence of eosinophils infiltrate.

The frequency of endocrine autoimmune disease with sarcoidosis is found to be significantly higher as compared to the general population. ${ }^{5}$ Thyroid autoimmunity is the most frequent autoimmune endocrine manifestation. ${ }^{4 \sim 6}$ Type 1 diabetes mellitus with sarcoidosis is less frequently shown. ${ }^{5,6}$ Our diabetic patient showed negative GAD-Ab, thyroglobulin antibody and thyroid peroxidase antibody, indicating type 2 diabetes mellitus without autoimmune thyroid disease.

The patient featured gradual serum creatinine increase with urine protein - to \pm . Urinary albumin excretion predicts an early stage of diabetic nephropathy. ${ }^{8}$ Although the urine $\mathrm{N}$-acetylglucosaminidase and $\beta 2$-microglobulin reflecting tubular dysfunction $^{9}$ were elevated, the urinary albumin excretion had been within normal range. Those urine findings may have been due to not diabetic nephropathy, but sarcoid interstitial nephritis. Moreover, her clouded vision was due to posterior uveitis without diabetic retinopathy reflecting diabetic microangiopathy. A renal biopsy also did not show diabetic nephropathy reflecting diabetic microangiopathy. Therefore, the renal dysfunction was due to

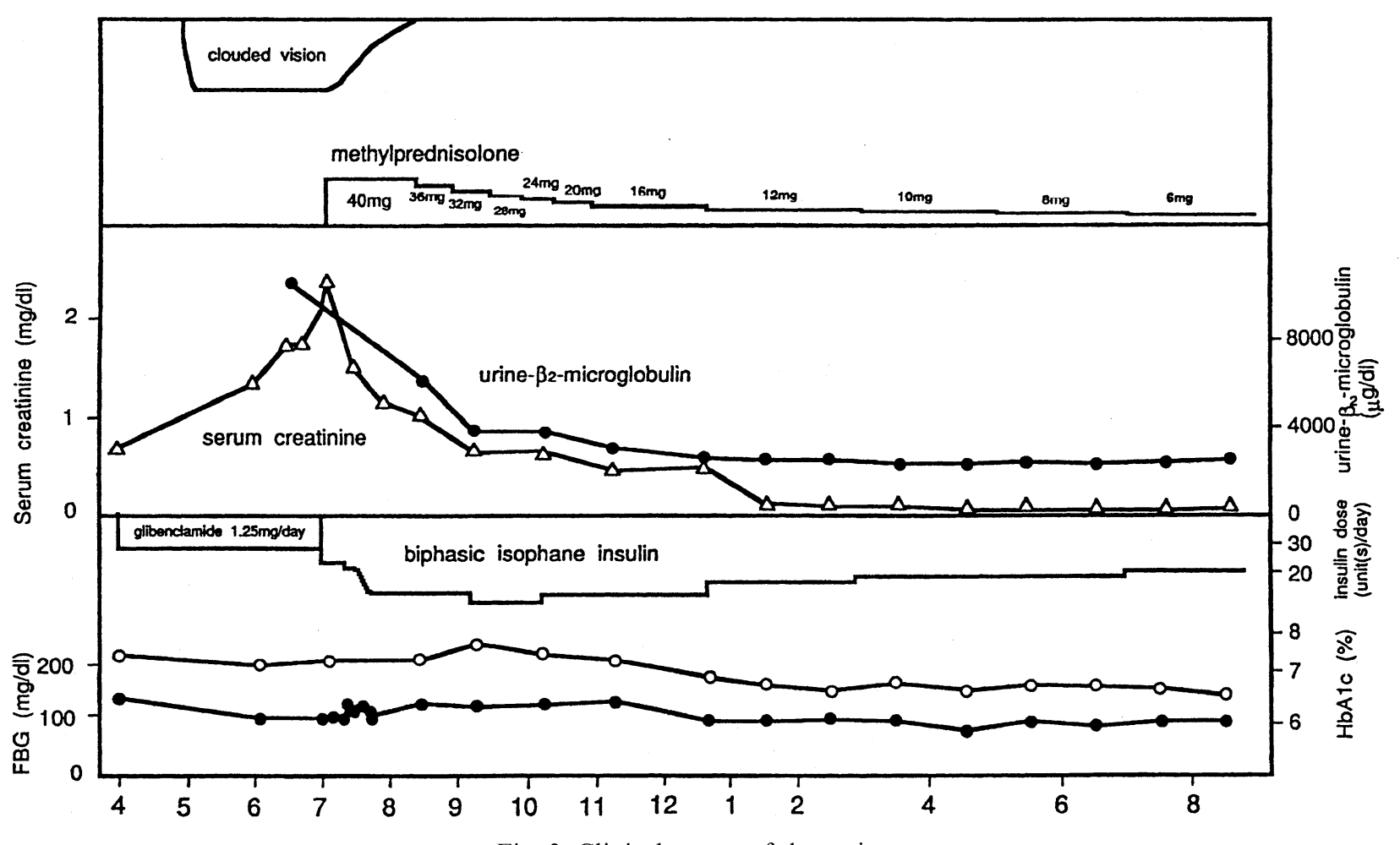

Fig. 3 Clinical course of the patient 
not diabetic nephropathy, but granulomatous interstitial nephritis.

Renal manifestation in sarcoidosis commonly consists of nephropathy related hypercalcemia (dehydration, nephrolithiasis, nephrocalcinosis) produced by the synthesis of active vitamin $\mathrm{D}$ in the granuloma. ${ }^{10}$ In our case, hypercalcemia, nephrolithiasis and nephrocalcinosis were not shown. Interstitial nephritis, with granuloma formation in some sarcoidosis cases, is another cause of renal failure, resulting from the activation of cellular immunity in renal tissues.

Pretreatment renal uptake of gallium-67 was negative whereas pulmonary uptake was positive. Serum ACE was not elevated in our case, although it is located in the sarcoid granuloma. ${ }^{11}$ Only one of 5 patients with sarcoid granulomatous interstitial nephritis has an elevated serum ACE at pretreatment. ${ }^{12}$ The fact that there was no renal uptake of gallium-67 or non-elevated serum ACE did not guarantee that sarcoidosis was not active in the kidneys. The diagnosis can only be made on renal biopsy.

Although we changed from glibenclamide to insulin therapy for blood glucose control after methylprednisolone treatment, clouded vision recovered and urine $\beta 2$-microglobulin returned to normal range. The steroid treatment response was good, in accord with that has been described by other investigators, ${ }^{13}$ suggesting that early diagnosis and treatment produces a certain reversibility of associated renal failure. We must notice the differential diagnosis from sarcoid renal lesion with diabetic nephropathy.

\section{References}

1. Kenouch S, Mery JP. The patient with sarcoidosis. In: Davison AM, et al (eds). Oxford Textbook of Clinical Nephrology. 2nd ed. Oxford : Oxford University Press, 1998 : 837-843.

2. Brause $\mathrm{M}$, Magnusson $\mathrm{K}$, Degenhardt $\mathrm{S}$, et al. Renal involvement in sarcoidosis-a report of 6 cases. Clnical Nephrol 2002 ; 57 : 142-148.

3. McCurley T, Salter J, Glick A. Renal insuffi- ciency in sarcoidosis. Arch Pathol Lab Med 1990 ; 114 : 488-492.

4. Hanock BW, Millard LG. Sarcoidosis and thyrotoxicosis. A study of five patients. $\mathrm{Br} \mathbf{J}$ Dis Chest 1976; 70 : 129-133.

5. Djrolo F, Gervaise N, Vaillant L, et al. Postpartum recurrent sarcoidosis associated with type 1 diabetes mellitus. Diabetes Metab 2003; 29 : 82-85.

6. Papadopoulos KI, Hornblad Y, Liljebladh H, et al. High frequency of endocrine autoimmunity in patients with sarcoidosis. Eur $\mathbf{J}$ Endocrinol 1996 ; 134 : 331-336.

7. Dobrin RS, Vernier RL, Fish AJ. Acute eosinophilic interstitial nephritis and renal failure with bone marrow lymph node granulomatous and anterior uveitis. Am J Med 1975; 59 : 325-327.

8. Mogensen CE. Microalbuminuria predicts clinical proteinuria and earlymortality in maturityonset diabetes. N Engl J Med 1984 ; 311 : 89-93.

9. Peterson PA, Evrin PE, Berggard I. Differentiation of glomerular, tubular and normal proteinuria: determinations of urinary excretion of $\beta 2$ microglobulin, albumin and total protein. J Clin Invest $1969 ; 48: 1189-1198$.

10. Singer FR, Adams JS. Abnormal calcium homeostasis in sarcoidosis. $N$ Engl $J$ Med 1986; 315: 755-757.

11. Ito $\mathrm{Y}$, Suzuki $\mathrm{T}$, Mizuno $\mathrm{M}$, et al. A case of renal sarcoidosis showing central necrosis and abnormal expression of angiotensin converting enzyme in the granuloma. Clin Nephrol 1994; 42: 331-336.

12. O'Riordan E, Willert RP, Reeve R, et al. Isolated sarcoid granulomatous interstitial nephritis : review of five cases at one center. Clin Nephrol 2001 ; 55 : 297-302.

13. Josep MC, Rafael P, Joan M, et al. Interstitial nephritis in sarcoidosis : simultaneous multiorgan involvement. Am J Kid Dis 1995; 26 : 947-951. 